\title{
DIAGNOSIS DAN PENATALAKSANAAN CEDERA SERVIKAL MEDULA SPINALIS
}

\author{
Junita Maja P. S. \\ Bagian Neurologi Fakultas Kedokteran Universitas Sam Ratulangi Manado \\ Email: junita.177ps@gmail.com
}

\begin{abstract}
Spinal cord injury is a traumatic lesion of the spinal cord which causes neurological disorders. The symptoms vary from pain, paralysis, and the occurence of incontinence, depending on the location of the injured spinal cord. The damage of the spinal cord may be incomplete or complete. We reported a 55-year-old male with his main complaint being weakness throughout all four limbs which occured after a fall with a hyperextended neck position. At the time of admission, the duration of injury was 12 hours. Physical examinations showed motoric and sensoric disorders, without any autonomic abnormalities. Cervical radiographics and a CT scan revealed no abnormalities, whereas the MRI images showed a contusion at C3. The management of this case included stabilization of the neck, a protocol treatment for cervical injuries, an administration of a high-dose of methylprednisolone, prevention of complications, and a regular session of physiotherapy. During treatment, the patient showed a significant progression in both motoric and sensoric functions. Conclusion: Based on all the tests performed and the follow-up, the diagnosis of this case was central cord syndrome (CCS) due to incomplete cervical medulla spinalis injury.
\end{abstract}

Keywords: cervical injury, spinal cord, diagnosis, treatment

\begin{abstract}
Abstrak: Trauma medula spinalis adalah trauma pada tulang belakang yang menyebabkan lesi di medula spinalis sehingga menimbulkan gangguan neurologik. Gejala-gejala dapat bervariasi mulai dari nyeri, paralisis sampai terjadinya inkontinensia, dan sangat bergantung pada lokasi medula spinalis yang mengalami cedera. Kerusakan medula spinalis dapat bersifat "inkomplit" dan "komplit”. Kami melaporkan kasus seorang laki-laki 55 tahun dengan kelemahan keempat anggota gerak yang terjadi setelah terjatuh dengan posisi leher yang hiperekstensi. Saat masuk rumah sakit, cedera sudah berlangsung selama 12 jam. Pada pemeriksaan fisik ditemukan gangguan motorik dan sensorik, sedangkan otonom tidak ditemukan kelainan. Gambaran radiologik foto servikal dan CT-Scan servikal tidak terdapat kelainan, sedangkan pada MRI tampak gambaran kontusio di segmen medula spinalis C3. Penanganan pada kasus ini yaitu stabilisasi leher, tatalaksana umum untuk cedera leher, pemberian metilprednisolon dosis tinggi, pencegahan komplikasi yang muncul, dan fisioterapi yang teratur. Selama perawatan pasien menunjukkan kemajuan yang berarti, baik dari fungsi motorik maupun sensorik. Simpulan: Berdasarkan hasil pemeriksaan yang telah dilakukan dan pemantauan lanjut selama perawatan, diagnosis yang ditegakkan ialah central cord syndrome (CCS) akibat cedera medula spinalis servikal inkomplit.
\end{abstract}

Kata kunci: cedera servikal, medula spinalis, diagnosis, tatalaksana

Cedera medula spinalis adalah trauma pada tulang belakang yang menyebabkan lesi medula spinalis sehingga terjadi gangguan neurologik, tergantung letak kerusakan saraf spinalis dan jaringan saraf yang rusak.
Gejala-gejala dapat bervariasi mulai dari nyeri, paralisis, sampai terjadinya inkontinensia. Kerusakan medula spinalis dapat dijelaskan dari tingkat "inkomplit" dengan gejala-gejala yang tidak berefek 
pada pasien sampai tingkat "komplit" dimana pasien mengalami kegagalan fungsi total. $^{1}$

Cedera medula spinalis pertama kali tercatat dalam sejarah sekitar 1700 SM pada papirus Edwin Smith. Penyebab cedera medula spinalis tersering ialah kecelakaan lalu lintas (50\%), jatuh (25\%), dan cedera yang berhubungan dengan olahraga (10\%); selain itu, akibat kekerasan dan kecelakaan kerja. Cedera medula spinalis akibat trauma diperkirakan terjadi pada 30-40 per satu juta penduduk per tahun, dan sekitar 8.000-10.000 penderita setiap tahun; umumnya terjadi pada remaja dan dewasa muda. Walaupun insidens per tahun relatif rendah, biaya perawatan dan rehabilitasi untuk cedera medula spinalis sangat tinggi, yaitu sekitar US\$ 53.000/pasien. ${ }^{1,2}$

Angka mortalitas diperkirakan 48\% dalam 24 jam pertama. Sekitar 80\% meninggal di tempat kejadian oleh karena vertebra servikalis memiliki risiko trauma paling besar, dengan level tersering $\mathrm{C}$, diikuti C4, C6, kemudian T12, L1, dan T10. Berdasarkan kecacatan yang terjadi, $52 \%$ kasus mengalami paraplegia dan $47 \%$ mengalami tetraplegia. ${ }^{2-4}$

\section{LAPORAN KASUS}

Seorang laki-laki berusia 55 tahun, pekerjaan petani, masuk rumah sakit tanggal 21 Februari 2012 dengan keluhan utama kelemahan keempat anggota gerak, yang dialami segera setelah terjatuh yaitu sekitar 12 jam sebelum masuk rumah sakit (MRS).

Pasien terjatuh saat sedang berjalan ke kebun oleh karena kakinya tersangkut rantai anjing, dengan kepala bagian belakang kanan membentur tanah pada posisi kepala tertekuk ke belakang. Kelemahan keempat anggota gerak langsung dirasakan saat itu, disertai rasa tebal pada keempat anggota gerak. Pasien hanya bisa mengangkat anggota gerak kemudian langsung terjatuh, sedangkan ujung anggota gerak atas tidak bisa digerakkan sama sekali.
Saat berada di rumah sakit, kelemahan anggota gerak dirasakan menetap sejak terjatuh. Pasien tidak mengeluhkan sesak napas, gangguan menelan, mual, muntah, penurunan kesadaran, kejang, batuk, dan demam. Keluhan seperti ini baru pertama kali dirasakan. Sejak terjatuh, pasien belum pernah buang air besar maupun kecil. Buang air besar terakhir satu hari sebelum MRS. Riwayat penyakit penyerta disangkal. Riwayat konsumsi alkohol sebanyak satu gelas kecil beberapa saat sebelum pasien berjalan ke kebun.

Pada pemeriksaan fisik status generalis ditemukan keadaan umum tampak sakit sedang. Status antropometri: berat badan 50 $\mathrm{kg}$, tinggi badan $160 \mathrm{~cm}$, dengan indeks massa tubuh $19,53 \mathrm{~kg} / \mathrm{m}^{2}$. Tanda-tanda vital dalam batas normal. Kulit berwarna kuning langsat, terdapat vulnus excoriatum di regio frontalis dekstra. Pemeriksaan fisik tidak menunjukkan kelainan.

Pemeriksaan neurologik menunjukkan GCS: $E_{4} M_{6} V_{5}=15$. Pupil bulat isokor pada kedua mata, diameter $3 \mathrm{~mm}$, simetris, refleks cahaya normal baik yang langsung maupun tidak langsung. Pemeriksaan nervus kranialis I - XII intak, dan pada funduskopi ODS tidak ditemukan tanda papil edema. Status motorik didapatkan trofi normal, tanpa fasikulasi dan klonus. Kekuatan otot menurun, yaitu: 1-1-4-3 pada ekstremitas atas bilateral; 2-4-3-3 pada ekstremitas kanan bawah; dan 3-3-4-2 pada ekstremitas kiri bawah. Tonus otot ekstremitas atas dan bawah normal. Refleks fisiologik normal, dan tidak dite-mukan refleks patologik. Status sensorik hipestesi eksteroseptif setinggi segmen medula spinalis C5 ke bawah, dengan proprioseptif terganggu. Pada status otonom tidak ditemukan inkontinensia urin et alvi.

Hasil pemeriksaan laboratorik darah di instalasi darurat medik umumnya dalam batas normal, kecuali kadar natrium yang agak rendah (126 mmol/L). Pada pemeriksaan EKG didapatkan incomplete RBBB. Pemeriksaan penunjang lainnya yaitu $X$ foto servikal AP/lateral dan X-foto toraks PA dalam batas normal. 
Diagnosis kerja yang ditegakkan ialah tetraparesis upper motor neuron (UMN) et causa trauma medula spinalis setinggi $\mathrm{C} 5$, disertai hiponatremia ringan.

Penatalaksanaan saat MRS ialah pemasangan neck collar, iv line $\mathrm{NaCl} 0,9 \%$ 500 cc tiap 8 jam, metilprednisolon 30 $\mathrm{mg} / \mathrm{kgBB}$ (1500 mg) dalam 15 menit, kemudian dilanjutkan setelah 45 menit 5,4 $\mathrm{mg} / \mathrm{kgBB} / \mathrm{jam}$ (270 $\mathrm{mg} / \mathrm{jam})$ selama 47 jam, Mecobalamin $500 \mathrm{mg}$ tiap 12 jam iv, ranitidin $50 \mathrm{mg}$ tiap 12 jam iv, Laktulosa sirup 3 x 1 sendok makan, dan rawat luka.

Pada perawatan hari ke-1 didapatkan keluhan nyeri pada leher dan rasa tebal pada keempat anggota gerak mulai membaik. Inspeksi regio vertebralis (log roll) tidak ditemukan jejas dan deformitas. Pada pemeriksaan colok dubur ditemukan tonus sfingter ani cekat, dan sacral sparring masih baik. Status motorik didapatkan trofi normal, tanpa fasikulasi dan klonus. Kekuatan otot masih menurun pada keempat ekstremitas walaupun sudah menunjukkan kemajuan. Pemeriksaan penunjang laboratorik dalam batas normal, kecuali gula darah 2 jam post prandial 197 $\mathrm{mg} / \mathrm{dL}$. Penatalaksanaan dengan rigid collar neck dan mobilisasi cara log roll. Terapi dilanjutkan dengan tambahan ketorolac $20 \mathrm{mg} 3$ x 1 tablet (jika nyeri). Diet lunak 1900 kkal dibagi atas empat porsi, protein $2 \mathrm{~g} / \mathrm{kgBB} /$ hari, takar urin, dan keseimbangan cairan tubuh.

Pada perawatan hari ke-2, kelemahan keempat anggota gerak dan rasa tebal pada keempat anggota gerak masih terasa. Hasil pemeriksaan Grading ASIA/IMSOP: D. Diagnosis kerja ialah Cervical 5 ASIA D; curiga spinal cord injury without radiologic abnormalities (SCIWORA). Program yang direncanakan oleh Bagian Rehabilitasi Medik ialah: breathing exercise, mobilisasi dengan neck collar, proper bed positioning, latihan isometrik servikal (Calliet exercise), latihan penguatan otot aktif resisted keempat ekstremitas; dan terapi dilanjutkan

Pada perawatan hari ke-3, keluhan masih tetap sama. Pemeriksaan gula darah sewaktu $152 \mathrm{mg} / \mathrm{dL}$, sedangkan yang lainnya dalam batas normal. Pemberian metil- prednisolon dilanjutkan dengan dosis 3x16 mg per oral yang secara bertahap diturunkan setiap 3 hari sampai dosis minimal 4 mg sehari; Mecobalamin dan ranitidin per oral; terapi lain dilanjutkan.

Pada perawatan hari ke-20 dilakukan CT-Scan servikal sentrasi C4-C6 dengan hasil dalam batas normal. Terapi dan program rehabilitasi dilanjutkan. Diagnosis kerja ialah Cervical 5 ASIA D; SCIWORA. Hasil MRI memperlihatkan pada T1 gambaran hipointens dan pada T2 gambaran hiperintens di medula spinalis segmen C3, dengan kesan kontusio medula spinalis C3 (Gambar 1).

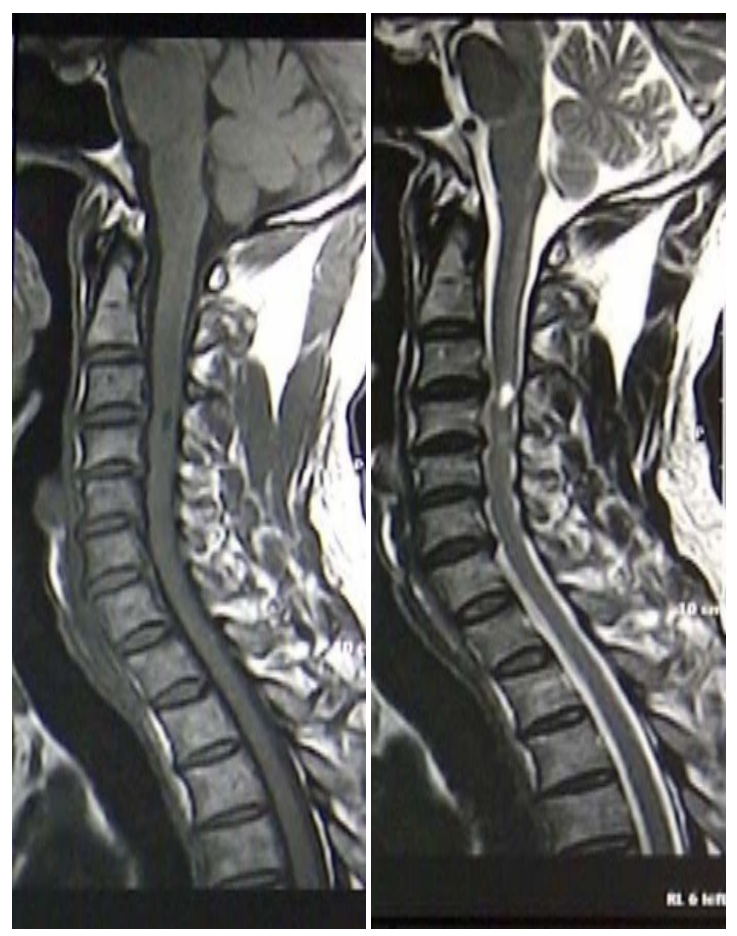

Gambar 1. Gambar MRI potongan sagital T1W (kiri) dan T2W (kanan)

Pada perawatan hari ke-29, keempat anggota gerak mengalami perbaikan. Kekuatan otot masing-masing ekstremitas (atas dan bawah) 4-4-4-4. Tonus otot ekstremitas atas dan bawah normal. Refleks fisiologik meningkat pada ke-empat ekstremitas, dan ditemukan refleks patologik pada kedua ekstremitas atas. Saat pulang, pasien dianjurkan untuk tetap menggunakan neck collar, Mecobalamin 
$500 \mathrm{mg} 3 \mathrm{x} 1$ tablet, dan kontrol teratur di poliklinik rehabilitasi medik.

\section{BAHASAN}

Trauma medula spinalis adalah trauma langsung atau tidak langsung pada tulang belakang yang menyebabkan lesi medula spinalis sehingga menimbulkan gangguan neurologik, yang dapat berakibat kecacatan menetap atau kematian. ${ }^{1}$ Tergantung letak kerusakan saraf spinalis dan jaringan saraf yang rusak, gejala-gejala dapat bervariasi mulai dari nyeri, paralisis, sampai terjadinya inkontinensia. Kerusakan medula spinalis dapat dijelaskan dari tingkat inkomplit dimana gejala-gejalanya tidak berefek pada pasien, sampai kerusakan komplit dimana pasien mengalami kegagalan fungsi total. ${ }^{5,6}$

Kerusakan medula spinalis tersering oleh penyebab traumatik, disebabkan dislokasi, rotasi, axial loading, dan hiperfleksi atau hiperekstensi medula spinalis atau kauda ekuina. Kecelakaan kendaraan bermotor merupakan penyebab tersering dari trauma medula spinalis, sedangkan penyebab lainnya ialah: jatuh, kecelakaan kerja, kecelakaan olahraga, dan penetrasi oleh tikaman atau peluru senjata api. Disamping trauma pada vertebra dan medula spinalis serta penyakit vaskuler, kerusakan medula spinalis juga dapat disebabkan keadaan non-traumatik seperti kanker, infeksi, dan penyakit sendi intervertebralis. ${ }^{1,2,5,6}$

Mekanisme tersering pada cedera medula spinalis ialah gaya translasional tidak langsung pada vertebra seperti hiperekstensi dan fleksi-rotasi (paling tidak stabil) mendadak yang mengakibatkan cedera medula spinalis. Cedera juga dapat diakibatkan oleh kompresi langsung pada medula spinalis. Pada beberapa kasus, terutama yang berusia muda ( $<8$ tahun), dapat terjadi cedera medula spinalis tanpa kerusakan tulang atau struktur disekitarnya (SCIWORA). ${ }^{3}$

Diagnosis kasus ini ditegakkan berdasarkan anamnesis, pemeriksaan fisik, dan pemeriksaan penunjang. Pada anamnesis ditemukan kelemahan anggota gerak yang terjadi secara tiba-tiba sesaat setelah pasien terjatuh dengan posisi kepala hiperekstensi disertai gangguan sensorik berupa rasa baal. Posisi jatuh dengan kepala hiperekstensi dapat menyebabkan peregangan ligamentum longitudinal anterior, yang merusak ruangan diskus vertebralis atau bagian marginal tulang vertebra. Hal ini mengakibatkan fraktur batas anterior superior atau inferior tulang belakang. Bagian posterior secara serentak mengalami kompresi, sehingga mengakibatkan fraktur prosesus spinosus, serta lamina dan permukaannya. ${ }^{4,5}$ Pada kasus ini tidak dijumpai fraktur tulang servikal.

Pada kasus ini pemeriksaan status motorik awal menunjukkan trofi normal, tanpa fasikulasi dan klonus. Pada keempat ekstremitas bilateral ditemukan kekuatan otot yang menurun sedangkan tonus otot normal. Refleks fisiologik masih normal, tidak ditemukan refleks patologik. Status sensorik hipestesi eksteroseptif setinggi segmen medula spinalis C5 ke bawah, dan proprioseptif terganggu. Inkontinensia urin et alvi tidak ditemukan.

Cedera medula spinalis dapat dibagi menjadi komplit dan inkomplit berdasarkan ada/tidaknya fungsi yang dipertahankan di bawah lesi (Tabel 1). Terdapat 5 sindrom utama cedera medula spinalis inkomplit menurut American Spinal Cord Injury Association, yaitu: (1) Central cord syndrome; (2) Anterior cord syndrome; (3) Brown-Sequard syndrome; (4) Cauda equina syndrome; dan (5) Conus medularis syndrome. Sindrom inkomplit yang sangat jarang terjadi yaitu Posterior cord syndrome (Tabel 2). Pada ilustrasi kasus di atas tipe sindrom cedera medula spinalis yang paling sesuai ialah central cord syndrome (CCS). ${ }^{3-8}$

CCS terjadi akibat cedera inkomplit pada bagian sentral segmen servikal medula spinalis, paling sering pada segmen servikal bagian tengah hingga bagian bawah. Kasus CCS di masyarakat sering terjadi melalui mekanisme cedera hiperekstensi pada kasus spondilosis servikal. Cedera tersebut terjadi akibat 
trauma yang mengakibatkan pendesakan ligamentum flavum (ligamen kuat yang saling menghubungkan lamina vertebra, berfungsi untuk melindungi saraf dan medula spinalis serta menstabilisasikan spina sehingga tidak terjadi pergerakan berlebihan pada vertebra) yang akhirnya menjepit medula spinalis dari posterior dan/atau akibat kompresi oleh osteofit atau material diskus dari anterior. ${ }^{5,9,10}$ Kompresi juga menyebabkan gangguan perfusi dari arteri spinalis anterior. Pada pemeriksaan fisik kasus CCS biasanya terbatas pada kelainan sistem neurologik, terdiri atas gabungan lesi UMN dan lower motor neuron (LMN) yang memasok ekstremitas atas dan mengakibatkan paralisis flaksid parsial; serta lesi yang lebih dominan pada UMN yang memasok ekstremitas bawah mengakibatkan paralisis spastik. Kelainan ekstremitas atas biasanya lebih parah daripada kelainan ekstremitas bawah, dan terutama terjadi pada otot-otot tangan bagian distal. Kehilangan kemampuan sensorik terjadi hingga derajat tertentu, meskipun sensasi sakral biasanya masih utuh. Kemampuan kontraksi anus dan tonus sfingter serta refleks Babinsky harus diperiksa. ${ }^{5,8,10,11}$

Pendapat lain menyebutkan bahwa kerusakan medula spinalis kemungkinan terjadi akibat kontusio medula spinalis. Kontusio ini terjadi karena medula spinalis terapung dalam cairan serebrospinal. Pada goncangan misalnya akibat terjatuh maka terjadi osilasi, yang bila tidak teratur dapat mengakibatkan benturan medula spinalis ke vertebra, dengan akibat terjadi stasis aliran aksoplasma, sehingga lebih cenderung terjadi cedera yang edematosa dari-pada hematomielia destruktif. ${ }^{5,7}$

Penelitian yang lebih mutakhir menemukan bahwa CCS mungkin terjadi akibat perdarahan ke bagian sentral medula spinalis, atau akibat disrupsi akson di kornu lateral pada level cedera namun tidak mengakibatkan kerusakan berarti pada substansia grisea. CCS juga dapat terjadi akibat fraktur dislokasi dan fraktur kompresi, khususnya pada individu yang mengalami penyempitan kanalis spinalis secara kongenital. Tekanan kompresi yang arahnya antero-posterior ini mengakibatkan kerusakan yang lebih parah di daerah sentral. Mekanisme cedera di atas mengakibatkan kerusakan yang paling parah pada bagian sentral medula spinalis dan kerusakan yang lebih ringan pada bagian perifer medula spinalis. Cedera pada area ini mengakibatkan kerusakan traktus spinotalamikus lateralis dan traktus kortikospinalisis dengan gejala yang khas (Tabel 2). ${ }^{12,13}$

Gangguan motorik maupun sensorik pada CCS terjadi akibat pola laminasi traktus kortikospinalis dan traktus spinotalamikus yang khas pada medula spinalis. Traktus spinotalamikus lateralis memiliki susunan laminasi dengan pola somatotopik, dimana serat-serat yang berasal dari segmen sakral terletak paling dorsolateral, selanjutnya oleh serat segmen lumbal dan torakal, sedangkan serat segmen servikal terletak paling ventromedial. Karena CCS disebabkan oleh cedera pada bagian sentral, maka serat-serat bagian servikal yang mengalami cedera parah sedangkan seratserat bagian sakral tidak mengalami cedera.

Tabel 1. Tabulasi perbandingan klinik lesi komplit dan inkomplit ${ }^{8}$

\begin{tabular}{lll}
\hline Karakteristik & Lesi komplit & Lesi inkomplit \\
\hline Motorik & Hilang di bawah lesi & Sering $(+)$ \\
Protopatik (nyeri, suhu) & Hilang di bawah lesi & Sering $(+)$ \\
Propioseptik (joint position, vibrasi) & Hilang di bawah lesi & Sering $(+)$ \\
Sacral sparing & Negatif & Positif \\
Radiologik vertebra & Sering fraktur, luksasi, atau listesis & Sering normal \\
& Hemoragi (54\%) & Edema (62\%) \\
MRI & Kompresi (25\%) & Kontusi (26\%) \\
& Kontusi (11\%) & Normal $(15 \%)$ \\
\hline
\end{tabular}


Tabel 2. Komparasi karakteristik klinik sindrom cedera medula spinalis ${ }^{2}$

\begin{tabular}{|c|c|c|c|c|}
\hline $\begin{array}{l}\text { Karakteristik } \\
\text { Klinik }\end{array}$ & $\begin{array}{l}\text { Central cord } \\
\text { syndrome }\end{array}$ & $\begin{array}{l}\text { Anterior cord } \\
\text { syndrome }\end{array}$ & $\begin{array}{l}\text { Brown-Sequard } \\
\text { syndrome }\end{array}$ & $\begin{array}{l}\text { Posterior cord } \\
\text { syndrome }\end{array}$ \\
\hline Kejadian & Sering & Jarang & Jarang & Sangat jarang \\
\hline Biomekanika & Hiperekstensi & Hiperfleksi & Penetrasi & Hiperekstensi \\
\hline Motorik & $\begin{array}{l}\text { Gangguan } \\
\text { bervariasi; } \\
\text { jarang paralisis } \\
\text { komplit }\end{array}$ & $\begin{array}{l}\text { Sering paralisis } \\
\text { komplit biasanya } \\
\text { bilateral; } \\
\text { gangguan traktus } \\
\text { desenden }\end{array}$ & $\begin{array}{l}\text { Kelemahan } \\
\text { anggota } \\
\text { gerak ipsilateral } \\
\text { lesi; gangguan } \\
\text { traktus desenden }\end{array}$ & $\begin{array}{l}\text { Gangguan } \\
\text { bervariasi, } \\
\text { gangguan traktus } \\
\text { desenden } \\
\text { ringan }\end{array}$ \\
\hline Protopatik & $\begin{array}{l}\text { Gangguan } \\
\text { bervariasi, } \\
\text { tidak khas }\end{array}$ & $\begin{array}{l}\text { Sering hilang } \\
\text { total bilateral; } \\
\text { gangguan traktus } \\
\text { asenden }\end{array}$ & $\begin{array}{l}\text { Sering hilang } \\
\text { total kontralateral; } \\
\text { gangguan traktus } \\
\text { asenden }\end{array}$ & $\begin{array}{l}\text { Gangguan } \\
\text { bervariasi, } \\
\text { biasanya ringan }\end{array}$ \\
\hline Propioseptik & $\begin{array}{l}\text { Jarang sekali } \\
\text { terganggu }\end{array}$ & Biasanya utuh & $\begin{array}{l}\text { Hilang total } \\
\text { ipsilateral; } \\
\text { gangguan traktus } \\
\text { asenden }\end{array}$ & Terganggu \\
\hline Perbaikan & $\begin{array}{l}\text { Sering nyata, cepat; } \\
\text { khas kelemahan } \\
\text { tangan dan jari } \\
\text { menetap }\end{array}$ & $\begin{array}{l}\text { Paling buruk di } \\
\text { antara lainnya }\end{array}$ & $\begin{array}{l}\text { Fungsi buruk, } \\
\text { namun } \\
\text { independensi } \\
\text { paling baik }\end{array}$ & ---- \\
\hline
\end{tabular}

Kerusakan inkomplit pada traktus ini mengakibatkan hilangnya kemampuan sensorik hingga batas-batas tertentu dalam penghantaran impuls rasa nyeri dan suhu; juga hilangnya kemampuan motorik yang berhubungan dengan rasa penuh pada kandung kemih, keinginan untuk miksi, serta rasa nyeri pada kandung kemih, uretra, dan ureter, yang mengakibatkan disfungsi kandung kemih. ${ }^{12,13}$

Kerusakan traktus kortikospinalisis dapat mengakibatkan hilangnya kemampuan untuk mengadakan pergerakan di bawah kemauan terutama pada bagian distal ekstremitas baik atas maupun bawah. Oleh karena tipe laminasi traktus kortikospinalis dengan serat-serat yang melayani tangan terletak lebih medial daripada serat-serat yang melayani kaki, maka cedera inkomplit di sentral segmen servikal medula spinalis akan mengakibatkan kelemahan ekstremitas atas yang lebih parah daripada ekstremitas bawah. Sendi-sendi yang terletak di sebelah proksimal maupun gerakan-gerakan yang bersifat kasar bisanya tidak terlalu terpengaruh. Jika terjadi cedera yang mengakibatkan perdarahan atau trombosis (seperti pada CCS) yang mengenai traktus ini, maka awalnya tonus otot-otot yang bersangkutan akan hilang. Setelah beberapa hari atau minggu, tonus otot akan kembali secara berangsurangsur hingga dapat terjadi spastisitas. Jika kerusakan serat UMN yang melayani ekstremitas bawah cukup berat, refleks Babinsky akan positif. ${ }^{1,12,13}$

Pemeriksaan penunjang yang disarankan meliputi pemeriksaan laboratorik darah dan pemeriksaan radiologik, dianjur-kan dengan 3 posisi standar (antero-posterior, lateral, dan odontoid) untuk vertebra servikal, serta posisi AP dan lateral untuk vertebra torakal dan lumbal. Pada kasus yang tidak menunjukkan kelainan radiologik, pemeriksaan lanjutan CTScan dan MRI sangat dianjurkan. MRI merupakan alat diagnostik yang paling baik untuk mendeteksi lesi medula spinalis akibat cedera/trauma. Pada pasien ini tidak ditemukan kelainan pada foto servikal AP/lateral dan CT-Scan servikal. Pemeriksaan MRI menunjukkan pada T1 tampak gambaran hipointens dan pada T2 tampak gambaran hiperintens di medula spinalis segmen C3, dengan kesan adanya kontusio pada medula spinalis C3. 
Bagian medula spinalis yang paling rentan ialah bagian dengan vaskularisasi yang paling banyak yaitu bagian sentral. Pada CCS, bagian yang paling menderita gaya trauma dapat mengalami nekrosis traumatik yang permanen. Edema yang terjadi dapat meluas sampai 1-2 segmen di bawah dan di atas titik pusat cedera. Sebagian besar kasus CCS menunjukkan hipo/isointens pada T1 dan hiperintens pada T2, yang mengindikasikan adanya edema.

Pasien ini didiagnosis dengan Servikal 5 ASIA D berdasarkan derajat cedera medula spinalis menurut skala ASIA /IMSOP (American Spinal Cord Injury Association/Internatonal Medical Society of Paraplegia). Skala penilaian ASIA/ IMSOP (Tabel 3) yang baru telah dikembangkan untuk membedakan cedera komplit maupun inkomplit. Untuk membedakan keduanya dilakukan tes tusuk jarum dan raba halus pada daerah dermatom L4 dan L5, daerah mukokutaneus perianal, sensasi anal dalam, serta kontraksi spinkter ani eksterna dengan pemeriksaan colok dubur. Perbedaan kedua jenis cedera ini memengaruhi perencanaan tatalaksana dan kemungkinan keluaran suatu cedera. ${ }^{5-8}$

Cedera inkomplit memiliki kemungkinan keluaran yang lebih baik dibandingkan cedera komplit servikal, torakal, atau torakolumbal. Studi lampau menyebutkan bahwa hampir tidak terjadi perbaikan pada cedera medula spinalis komplit. Hasenbout mengemukakan bahwa dalam tinjauan komprehensif dari serial kasus yang luas, hanya $1-2 \%$ pasien dengan cedera medula spinalis komplit dapat berjalan. ${ }^{1}$ Keadaan ini disebabkan kesulitan saat pemeriksaan neurologik awal, terutama pada pasien dalam keadaan mabuk, pengaruh obat-obat penenang, syok spinal, gegar otak, atau tidak kooperatif oleh karena hal-hal lain. Cedera medula spinalis komplit yang bisa mengalami perbaikan dapat diidentifikasi dengan tes elektrofisiologi yang menunjukkan serabut saraf yang masih intak pada stadium subakut maupun kronik. Studi otopsi menunjukkan bahwa pada cedera medula spinalis komplit masih terdapat daerah anatomi yang intak. ${ }^{1}$

Terapi pada kasus cedera medula spinalis terutama ditujukan untuk meningkatkan dan mempertahankan fungsi sensorik dan motorik. Pasien dengan cedera medula spinalis komplit hanya memiliki peluang 5\% untuk kembali normal. Lesi medula spinalis komplit yang tidak menunjukkan perbaikan dalam 72 jam pertama, cenderung menetap dan prognosisnya buruk. Cedera medula spina-lis inkomplit cenderung memiliki prognosis yang lebih baik. Bila fungsi sensorik di bawah lesi masih ada, maka kemungkinan untuk kembali berjalan $>50 \%$.

Metilprednisolon merupakan terapi yang paling umum digunakan untuk cedera medula spinalis traumatika dan direkomendasikan oleh National Institute of Health di Amerika Serikat. Penggunaannya sebagai terapi utama cedera medula spinalis traumatika masih dikritik oleh banyak pihak dan belum digunakan sebagai terapi standar. Kajian Braken dalam Cochrane

Tabel 3. Klasifikasi derajat cedera medula spinalis menurut ASIA/IMSOP ${ }^{1}$

\begin{tabular}{|c|c|c|}
\hline Tingkat & Tipe & Gangguan medula spinalis \\
\hline A & Komplit & Tidak ada fungsi motorik dan sensorik sampai S4-S5 \\
\hline B & Inkomplit & $\begin{array}{l}\text { Fungsi sensorik masih baik tapi motorik terganggu sampai } \\
\text { segmen sakral S4-S5 }\end{array}$ \\
\hline $\mathrm{C}$ & Inkomplit & $\begin{array}{l}\text { Fungsi motorik terganggu dibawah level tapi otot-otot } \\
\text { motorik utama masih mempunyai kekuatan }<3\end{array}$ \\
\hline $\mathrm{D}$ & Inkomplit & $\begin{array}{l}\text { Fungsi motorik terganggu dibawah level, kekuatan otot-otot } \\
\text { motorik utama }>3\end{array}$ \\
\hline $\mathrm{E}$ & Normal & Fungsi motorik dan sensorik normal \\
\hline
\end{tabular}


Library menunjukkan bahwa metilprednisolon dosis tinggi merupakan satusatunya terapi farmakologik yang terbukti efektif pada uji klinik tahap 3, sehingga obat ini dianjurkan sebagai terapi cedera medula spinalis traumatika. Mekanisme kerja metilprednisolon ialah menurunkan respon inflamasi dengan menekan migrasi netrofil dan menghambat peningkatan permeabilitas vaskular. Metilprenidsolon menghambat kerja lipid peroksidase dan hidrolisis sehingga dapat menghambat destruksi membran sel. Kerusakan membran sel mencapai puncak sekitar 8 jam; oleh karena itu, metilprednisolon harus diberikan dalam rentang waktu tersebut. Lipid peroksidase mengacu pada degradasi oksidatif lipid, yaitu proses dimana radikal bebas "mencuri" elektron dari lipid pada membran sel, yang mengakibatkan kerusakan sel. $^{2,5-7}$

Pencegahan komplikasi sangat berperan penting. Tindakan rehabilitasi medik merupakan kunci utama dalam penanganan pasien cedera medula spinalis. Fisioterapi, terapi okupasi, dan bladder training harus dilakukan sedini mungkin. Tujuan utama fisioterapi ialah untuk mempertahankan range of movement (ROM) dan kemampuan mobilitas, dengan memperkuat fungsi otot-otot. Terapi okupasional terutama ditujukan untuk memperkuat dan memperbaiki fungsi ekstremitas atas, serta mempertahankan kemampuan aktivitas hidup sehari-hari. Pembentukan kontraktur harus dicegah seoptimal mungkin. ${ }^{1,2,5-7}$

Prognosis bonam pada kasus ini karena selama perawatan pasien mengalami perbaikan neurologik yang berarti. Pasien CCS yang berusia $<50$ tahun biasanya memiliki prognosis baik; dalam waktu singkat $97 \%$ kasus mengalami kesembuhan, memperoleh kembali kemampuan mobilisasi, dan dapat melakukan kegiatan harian dengan normal. Pasien berusia $>50$ tahun memiliki prognosis lebih buruk; hanya $17 \%$ kasus yang mengalami kesembuhan. Bila penyebab CCS ialah edema, gejala dapat membaik dalam waktu singkat. Fungsi kaki biasanya akan kembali lebih dulu. Gerakan lengan bawah dan jari tangan biasanya memerlukan waktu yang paling lama untuk kembali normal. Bila lesi disebabkan oleh perdarahan atau iskemia, prognosis biasanya lebih buruk dan penyembuhan spontan sulit terjadi.

Faktor yang memengaruhi prognosis antara lain: tingkat keparahan kelemahan ekstremitas atas, pulihnya fungsi motorik dalam waktu singkat, peningkatan yang signifikan pada kekuatan ekstremitas atas maupun bawah pada tahap awal rehabilitasi, usia yang lebih muda, serta tidak terdapat kelainan neurologik pada ekstremitas bawah. ${ }^{10,11}$

\section{SIMPULAN}

Telah dilaporkan kasus cedera servikal medula spinalis yang inkomplit. Penatalaksanaan dengan stabilisasi leher, tatalaksana umum cedera leher, pemberian metilprednisolon dosis tinggi, pencegahan komplikasi, dan fisioterapi teratur. Setelah perawatan, pasien menunjukkan kemajuan yang berarti, baik fungsi motorik maupun sensorik.

\section{DAFTAR PUSTAKA}

1. Narayan RK, Wilberger JE, Povlishock JT. Spinal cord injury. In: Narayan RK, editor. Neurotrauma Vol II. Mc-GrawHill. New York. 1996; II;1041-112.

2. Derwenskus J, Zaidat O. Spinal cord injury and related disease. In: Suarez JI, editor. Critical Care Neurology and Neurosurgery. New Jersey: Humana Pres, 2004; 433-48.

3. Kelompok Studi Neurotraumatologi. PERDOSSI. Konsensus Trauma Kepala dan Medula Spinalis. 2006.

4. Basuki A. Cedera medula spinalis akut. In: Basuki A, Dian S, editors. Kegawatdaruratan Neurologi. Bandung: Bagian/UPF Ilmu Penyakit Saraf FK UNPAD/RSHS, 2010; p. 123-49.

5. Baskin DS. Spinal cord injury. In: Evans RW, editor. Neurology and Trauma. New York: Oxford University Press, 2006; p. 265-344.

6. Sullivan SJ, Hassan DG. Spinal trauma. In: Manji H, Connolly S, Dorward N, Kitchen N, Mehta A, Wils A, editors. 
Neurotrauma. Oxford American Handbook of Neurology. Philadelphia: Oxford University Press, 2010; p. 35665.

7. Brown J, Johnston RA. Acute spinal cord compression. In: Hughes RAC, editor. Neurological Emergencies (Fourth Edition). London: BMJ Books, 2003; p. 345-76.

8. Ropper A, Samuels MA. Spinal cord disorder in trauma. Adams and Victor's Principles of Neurology (Ninth Edition). New York: McGraw-Hill, 2009. p. 1181-89.

9. Dillman D, Brambrink A. Spinal cord injury. In: Bhardwaj A, Ellegala DB, Kirsch JR, editors. Acute Brain and Spinal Cord Injury, Evolving Paradigms and Management. New
York: Informa Healthcare, 2008; p. 357-414.

10. Sadowsky C, McDonald JW. Spinal cord injury. The Lancet. 2002;359:417-25.

11. Pinzon R. Mielopati servikal terkini: Telaah pustaka terkini. Cermin Dunia Kedokteran. 2007;154:39-42.

12. Baehr M, Frotscher M. Motor system. In: Topical Diagnosis in Neurology: Anatomy, Physiology, Signs, Symptoms (Fourth Edition). New York: Thieme, 2005; p. 57-115.

13. Snell RS. Medula spinalis serta tractus ascendens dan descendens. In: Sugiharto L, alih bahasa; Dimanti A, Hartanto H, editors. Neuroanatomi Klinik (Edisi Kelima). Jakarta: EGC, 2002; p. 150-210. 